\title{
Instantaneous Determination of Heat Transfer Coefficients in a Steam Generator for an Alternative Energy Upgrade System
}

\author{
Sotsil Silva Sotelo ${ }^{\mathrm{a}}$, Rosenberg J. Romero, ${ }^{* \mathrm{a}}$ and Roberto Best ${ }^{\mathrm{b}}$ \\ ${ }^{a}$ Centro de Investigación en Ingeniería y Ciencias Aplicadas, Universidad Autónoma del Estado de Morelos, Av. Uni- \\ versidad 1001, Col. Chamilpa, C.P. 62209, Cuernavaca Morelos, México \\ ${ }^{b}$ Centro de Investigación en Energía, Universidad Nacional Autónoma de México, Privada Xochicalco s/n, C.P. 62580, \\ Temixco Morelos, México
}

\begin{abstract}
The present work shows a mathematical model to determine the thermal behavior of a steam generator in an alternative energy upgrade system. In this system, alternative energy (solar, geothermal or waste heat from an industrial process) is upgraded to a higher temperature, through a thermodynamic cycle. A plate heat exchanger is used as the steam generator, and is a key component in the system. A mixture of water-lithium bromide + ethylene glycol was used as working solution. The steam generator works with alternative energy, this is used to evaporate a part of the working solution inside the steam generator. The temperature profile and the heat transfer coefficients were obtained with type $T$ thermocouples placed along the plate heat exchanger. The conditions that produce the highest heat transfer coefficients for the alternative energy system and the calculated heat transfer coefficients for the working solution are shown. This is the first work where a plate heat exchanger is used as a steam generator in an energy upgrade system and the first time that has been calculated the heat transfer coefficients for the working solution. There are no previous data of the use of the working solution on steam generators.
\end{abstract}

Keywords: Alternative energy, heat transfer coefficients, temperature profile, novel working solution, absorption heat transformer.

\section{INTRODUCTION}

The world faces one main problem, global warming, consequence of the increase in greenhouse gas concentrations, resulting from human activity such as fossil fuel burning. Main consumer of fossil fuel is the industrial sector [1], where high temperatures are necessary for the processes or chemical reactions. Besides the pollution caused by using fossil fuel, it is important to say that the reservations of this fuel are ending, therefore, it is necessary to look for alternative energies. This type of energies (such as solar, geothermal, or waste heat from industrial processes) can be used in absorption systems. Absorption heat pumps (AHP) are equipments able to operate with this type of energy. AHP could be used for cooling (such as air conditioner or refrigeration systems) and for heating (delivering heat at high temperature). The absorption heat pumps use a working solution composed by an absorbent and a working fluid. Among the most common working solutions in these systems are: water - lithium bromide (where the working fluid is water) and ammonia-water (ammonia is the working fluid). Another solution that has been proved in AHP is waterCarrol $^{\mathrm{TM}}$ (lithium bromide + ethylene glycol in a ratio 4.5:1,

*Address correspondence to this author at Centro de Investigación en Ingeniería y Ciencias Aplicadas, Universidad Autónoma del Estado de Morelos, Av. Universidad 1001, Col. Chamilpa, C.P. 62209, Cuernavaca Morelos,

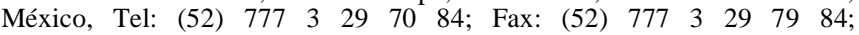
E-mail: rosenberg@uaem.mx

1876-3871/09 percentage in weight). This solution designed by Carrier Co., was originally proposed for systems of air conditioning [2], however, it has been evaluated experimentally in AHP [3], showing some advantages in comparison with other solutions.

Water-Carrol ${ }^{\mathrm{TM}}$ has a higher operation range, for its superior solubility compared to water-lithium bromide solution. Water-lithium bromide solution has a crystallization risk at concentrations higher to $65 \%$, water-Carrol ${ }^{\mathrm{TM}}$ presents crystallization risk at concentrations higher to $70 \%$.

These equipments have enormous potential for reducing the primary energy requirements by low grade energy transformation $[4,5]$. The AHP that delivers heat at high temperatures is called Absorption Heat Transformer (AHT). Through a thermodynamic cycle of absorption, an AHT increases the temperature of the alternative energy source to a higher level. There are two types of AHT, Single Stage Heat Transformer (SSHT) and Double Stage Heat Transformer (DSHT). The DSHT has the configuration of two SSHT coupled, where the useful heat from one is added to the other [6].

The AHT can be used in any industrial process where low temperature heat flow occurs. Scarcely any valuable mechanical or electrical energy is needed as drive power [7]. The main applications of AHT are for industrial processes and for using solar energy. In 2002, it was reported that there were 15 AHT operating in industrial plants worldwide [8]. 
Economical evaluations have been reported for equipments in different industries. The economical evaluation is done in comparison with the consumption of primary energy. It has been reported that with a SSHT, is possible to achieve $45 \%$ of primary energy saving, and, with a DSHT $60 \%$, in comparison in an industry without this type of systems [9]. The economic feasibility of transform low temperature waste heat $\left(80-100{ }^{\circ} \mathrm{C}\right)$ into a useful heat of $90-160{ }^{\circ} \mathrm{C}$ has been evaluated. An AHT was designed with a useful performance of $4 \mathrm{MW}$, showing a period of return on investments of 2.3 years. It is considered that the price of the waste heat is nil [7]. The installation of an AHT has been reported in a synthetic rubber plant in China, the waste heat is used to heat water up to $110{ }^{\circ} \mathrm{C}$, and this stream of water is returned to another part of the process. The energy saving by installing the AHT into the industrial process was evaluated with the difference of the steam consumption before and after the AHT system being installed, the steam consumption per ton of rubber was reduced from 2.53 ton before to 1.04 ton now. Besides, diminishing the steam consumption, 2337 tons of exhaust gas were given off to the air environment (including $\mathrm{SO}_{2}$, NOx, CO) [10]. Costa et al. [11] show a proposal of installation of a DSHT in a pulp and paper plant, with waste vapor supplied to the AHT, therefore $17 \mathrm{t} / \mathrm{h}$ of LP steam could be obtained. Considering all the reductions in energy supplied, the pay back time for the investment is 1.6 years. Huicochea et al., [12], reported the application of an AHT for water purification, the quality of the obtained water is comparable to that from a laboratory distiller; also there is a proposal to couple this equipment to plane solar collectors [13]. AHP can be used in high capacity desalination plants, especially in areas where there is a lack of fresh water [14]. Sözen and Yücesu [15] proposed to use an AHT to increase the temperature of a solar pond; the simulation shows that it is possible to obtain useful heat at $150{ }^{\circ} \mathrm{C}$.

There is a lack of information about steam generation in absorption machines. Shitara y Nishiyama reported the study of a compact heat exchanger with different fluids arrangement [16]. Roriz et al., and Táboas et al., evaluated the working mixture ammonia-water in a plate heat exchanger (PHE); they are used as steam generators in absorption machines for refrigeration $[17,18]$. Rivera et al. reported the heat transfer coefficients of steam generation in solar absorption refrigeration systems, for the mixtures ammonia-water, ammonia-lithium nitrate and water-lithium bromide [19, 20]. So far, there are no works about steam generators using the mixture water-Carrol ${ }^{\mathrm{TM}}$. Instead, for this work, the data reported for boiling fluids in plate heat exchangers were considered [21-24].

The heat pumps have different components depending on the process that they carry out (compression or absorption). The absorption heat pumps have the advantage of not using refrigerants that are noxious to the atmosphere, an absorption cycle substitutes the compression process. The main components of an absorption heat pump are: absorber, generator, condenser, evaporator, economizer, expansion valve and pumps.

The heat pumps can be classified by its temperature levels [25]:
Heat pumps type 1: the temperature of the evaporator is lower that the temperature of the condenser (compression and absorption heat pumps) $\mathrm{T}_{\mathrm{EV}}<\mathrm{T}_{\mathrm{CO}}$.

Heat pumps type 2 (or absorption heat transformer): the temperature of the evaporator is higher than the temperature of the condenser. $\mathrm{T}_{\mathrm{EV}}>\mathrm{T}_{\mathrm{CO}}$.

\section{ABSORPTION HEAT TRANSFORMER}

An AHT has three levels of temperature and two levels of pressure. Fig. (1) shows a schematic diagram in axes of pressure against temperature. Alternative energy is supplied (at intermediate temperature and atmospheric pressure) to the generator and the evaporator $\left(\mathrm{T}_{\mathrm{GE}}, \mathrm{T}_{\mathrm{EV}}\right)$, in the generator carries out the steam generation, changing the concentration of the working solution. The working fluid is condensed in the condenser, delivering a quantity of heat at low temperature $\left(\mathrm{T}_{\mathrm{CO}}\right)$. Then the working fluid goes to the evaporator through the expansion valve (reducing its pressure) where it is evaporated at the same temperature as that of the generator. The vapor goes to the absorber, where the solution coming from the generator absorbs it, delivering heat at high temperature $\left(\mathrm{T}_{\mathrm{AB}}\right)$, which is the useful heat (upgrade energy) obtained from the alternative energy. Finally, the solution goes to the generator starting the cycle again. Between the absorber and the generator, a heat exchanger is placed (economizer); its function is to preheat the solution coming from the generator.

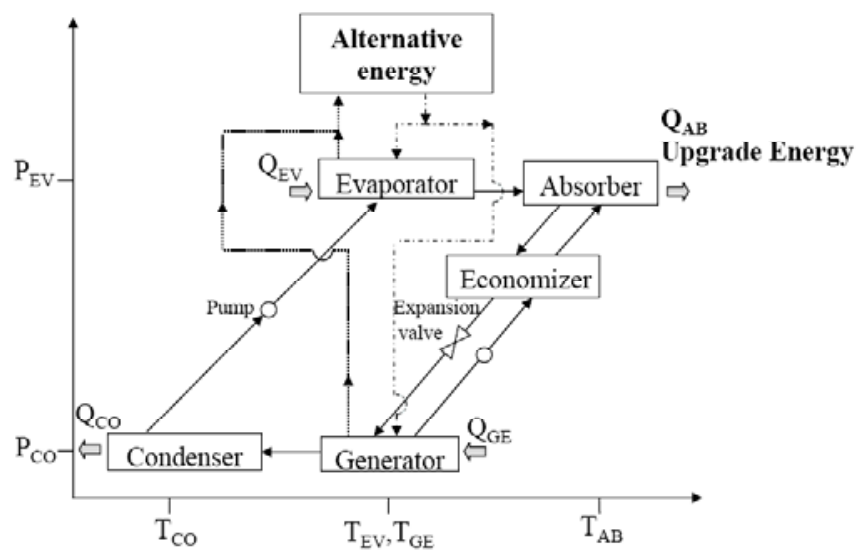

Fig. (1). Schematic diagram of an absorption heat transformer.

The steam generator is the starter component of the AHT cycle. The steam generated, goes to the condenser and evaporator, and, finally, when the working solution absorbs the steam, heat at high temperature is obtained. Without the steam generation, there would not be absorption or useful heat. A better understanding of the steam generation process will allow a more efficient operation of the system and, a better use of the alternative energy source. The efficiency in the heat transfer in the generator has a significant impact in the performance of the AHT. Therefore, a mathematical model for the simulation of the heat transfer in the generator is presented to determine instantaneously, the best operation conditions in the generator. There are no previous works in a steam generator operating with this working solution. 


\section{METHODOLOGY}

\section{Test Rig}

The experimental set up is an AHT where the main components are plate heat exchangers. As far, there are not previous works in AHT where the five components are PHE. This type of heat exchangers have many advantages in comparison to others: they are compact equipments with big heat transfer areas, they are easy to clean, and it is possible to modify the transfer area changing the number of plates. The generator is a horizontal heat exchanger, with seven plates. Two plates form a channel. There are six channels, in three of them flows the working solution and in the three remaining, water of the heater system (alternative energy). So far, we do not have an alternative energy source; instead electric resistance simulates the alternative energy. With an electric relay, it is possible to fix the temperature and to maintain it during the experimental test. The temperature is fixed between 75 and $90{ }^{\circ} \mathrm{C}$. It is possible to reach this temperature by plane solar collectors and solar ponds [26, 27]. The flows of the heater system are controlled by a valve and a flow meter. It is not possible to place thermocouples inside the PHE; instead, ten thermocouples were placed in the wall of the plate, in the two first channels. Fig. (2) shows a diagram of the flows in the generator and the location of the thermocouples in the two first channels. The thermocouples are connected to a data logger that measures the temperatures every ten seconds. These temperatures are sent to the program to calculate instantly the heat transfer coefficients. With the instantaneous determination of the heat transfer coefficients, it is possible to modify some parameter during the experimental test, like mass flow of the alternative energy source, and observe if that modification has an impact in the performance of the system. Also all the data are being sent to an Excel $^{\mathrm{TM}}$ file.

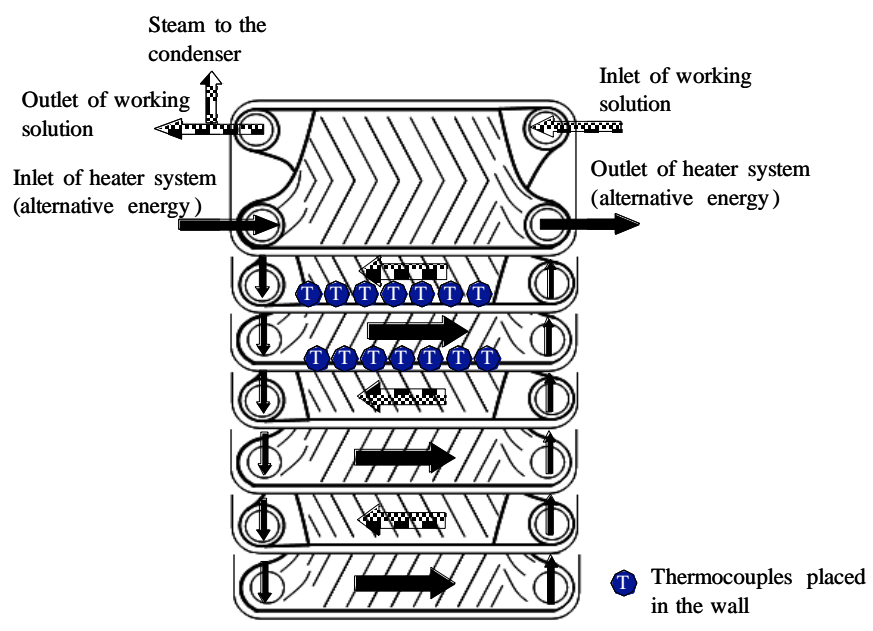

Fig. (2). Plate heat exchanger as the steam generator.

\section{MATHEMATICAL MODEL}

The mathematical model considers the heat transferred to the working solution by the alternative energy system and the changes in the concentration of the working solution. The model was programmed in Vee Pro@ 7.5 Software by Ag- ilent Technologies. Fig. (3) shows a diagram for the steam generation.

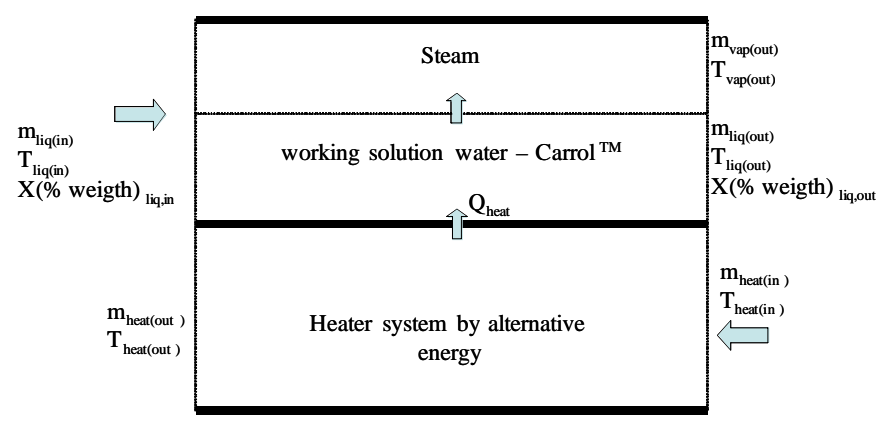

Fig. (3). Diagram of the steam generation process.

The heater system and working solution flows in countercurrent. A quantity of water is evaporated from the working solution. The heat transferred to the solution is:

$Q_{\text {heat }}=m_{\text {heat }}\left(H_{\text {heat }, \text { out }}-H_{\text {heat }, \text { in }}\right)$

The heat transfer equation is:

$q_{\text {heat }}=U A \Delta T_{l m}$

The global heat transfer coefficient $\mathrm{U}$ is:

$$
U=\frac{1}{\frac{1}{h_{\text {heat }}}+\frac{\Delta z}{k_{s s}}+\frac{1}{h_{\text {liq }}}}
$$

The heat transfer coefficients for the heater system were calculated with two equations, previously reported for single phase flow in PHE. The equation of Bogaert \& Bölcs [28]:

$$
h_{\text {heat }}=0.2634\left(\frac{k_{\text {heat }}}{D_{h}}\right) \operatorname{Re}^{0.7152} \operatorname{Pr}^{\frac{1}{3} e\left(\frac{6.4}{\operatorname{Pr}+30}\right)}
$$

And the equation of Chisholm and Wanniarachchi [29]:

$$
h_{\text {heat }}=0.724\left(\frac{k_{\text {heat }}}{D_{h}}\right)\left(\frac{6 \beta}{\pi}\right)^{0.646} \operatorname{Re}^{0.583} \operatorname{Pr}^{\frac{1}{3}}
$$

Where $\beta$ is the angle of the plate $\left(60^{\circ}\right)$ and $D_{h}$ is the hydraulic diameter.

The heat transfer coefficient for the working solution is calculated as follows:

$$
\frac{1}{h_{\text {liq }}}=\frac{1}{U}+\frac{1}{h_{\text {heat }}}+\frac{\Delta z}{k_{\text {wall }}}
$$


The concentration and the physical properties of the working solution are determined by the equations published by Reimann and Biermann [30].

\section{RESULTS}

With the measures of the thermocouples placed in the generator it was possible to determine the temperature profiles for the heater system (that use the alternative energy source) and the profile of the working solution. With the determination of the thermal behavior in the generator, it will be possible to estimate the quantity of alternative energy upgraded in the absorber. Fig. (4) shows the profile for the heater system.

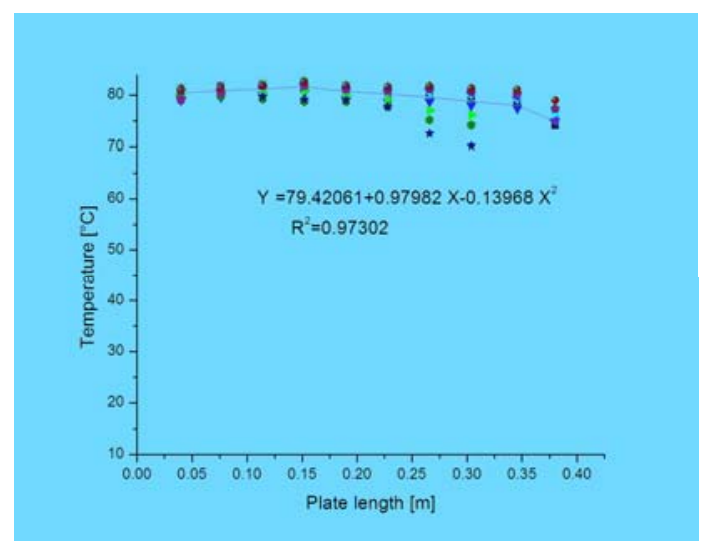

Fig. (4). Profile of the heater system.

Fig. (5) shows the temperatures profile for the working solution and the heater system in the first channel.

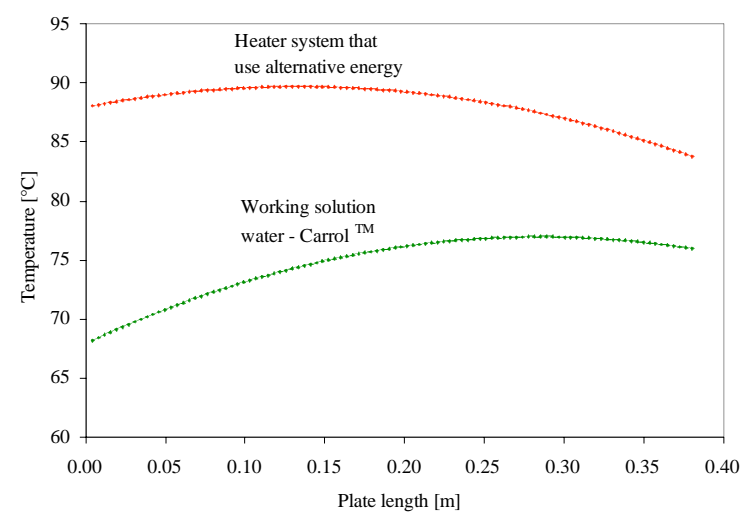

Fig. (5). Temperature profiles of the heater system and the working solution.

Fig. (6) shows the heat transfer coefficients for three different flows $(2.6$ to $3.3 \mathrm{~L} / \mathrm{min})$ of the heater system with alternative energy. The flows selected, were tested in the AHT, obtaining satisfactory results.

It is possible to observe that the heat transfer coefficients are almost constant along the plate. The differences of the values obtained by the two correlations are 11.8 to $20.4 \%$. The mass flow considered, is the total mass flow that enters

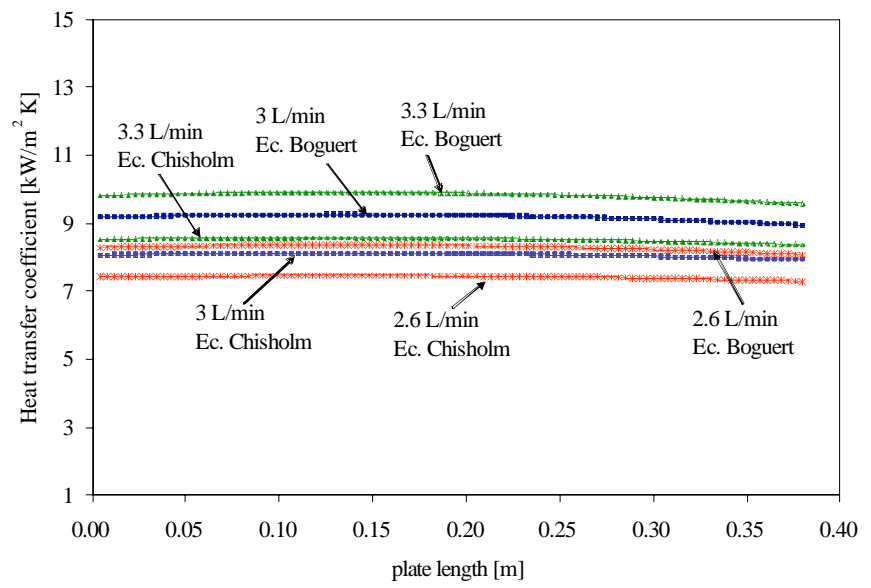

Fig. (6). Heat transfer coefficients for the heater system.

to the PHE divided in three channels for the heater system. Fig. (7) shows the values of the average heat transfer coefficients for different mass flows, with the equations 4 and 5, it is important to stand out that for relative low mass flows (1.3 and $2 \mathrm{~L} / \mathrm{min}$ ) of the heater system, the values of both correlations are very close, this difference is increasing with the highest mass flows. This could be explained by the exponential term in the equation of Bogaert \& Bölcs.

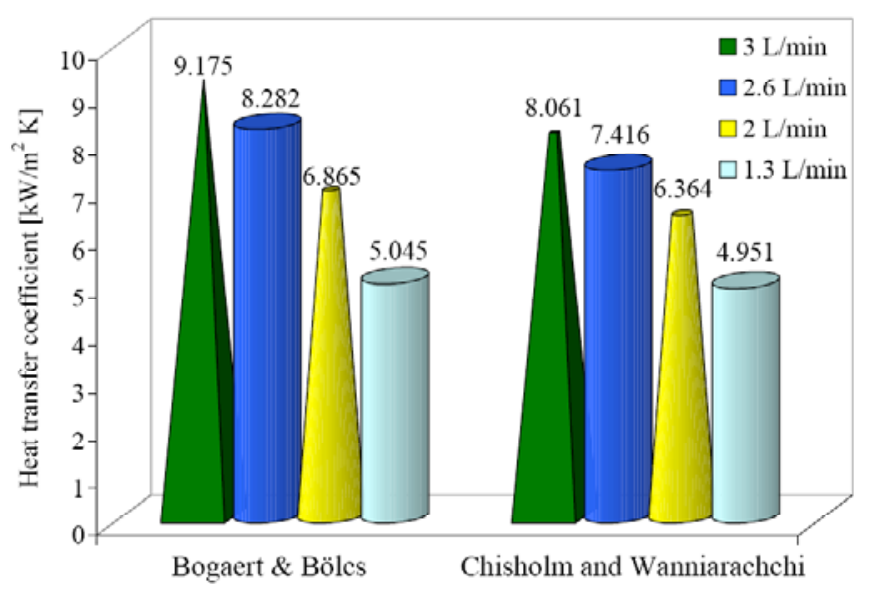

Fig. (7). Average heat transfer coefficients for different mass flows.

Fig. (8) shows the heat transfer coefficients only with equation 5 ; in this graph it is possible to observe that the increase in the mass flow is not lineal to the increase in the value of the coefficient. With a mass flow of $2 \mathrm{~L} / \mathrm{min}$ an average heat transfer coefficient of $6.3 \mathrm{~kW} / \mathrm{m}^{2} \mathrm{~K}$ is obtained and for a mass flow of $4 \mathrm{~L} / \mathrm{min}$ the average heat transfer coefficient is of $10.3 \mathrm{~kW} / \mathrm{m}^{2} \mathrm{~K}$.

Fig. (9) shows the variations of the average heat transfer coefficient with different Reynolds numbers and for three different temperatures of the alternative energy source. The heat transfer coefficient increase with the Reynolds number, this behavior is similar as reported for Hsieh and Lin for a plate heat exchanger [31]. The highest heat transfer coefficient of $11.2 \mathrm{~kW} / \mathrm{m}^{2} \mathrm{~K}$ corresponds to a Reynolds number of 2310. This Reynolds number is obtained at temperature of $90{ }^{\circ} \mathrm{C}$. 


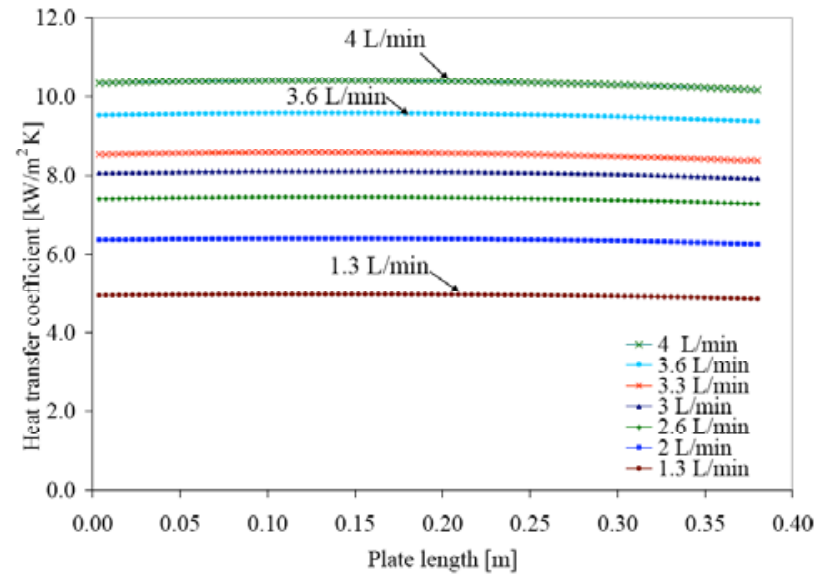

Fig. (8). Heat transfer coefficients for the equation of Chisholm.

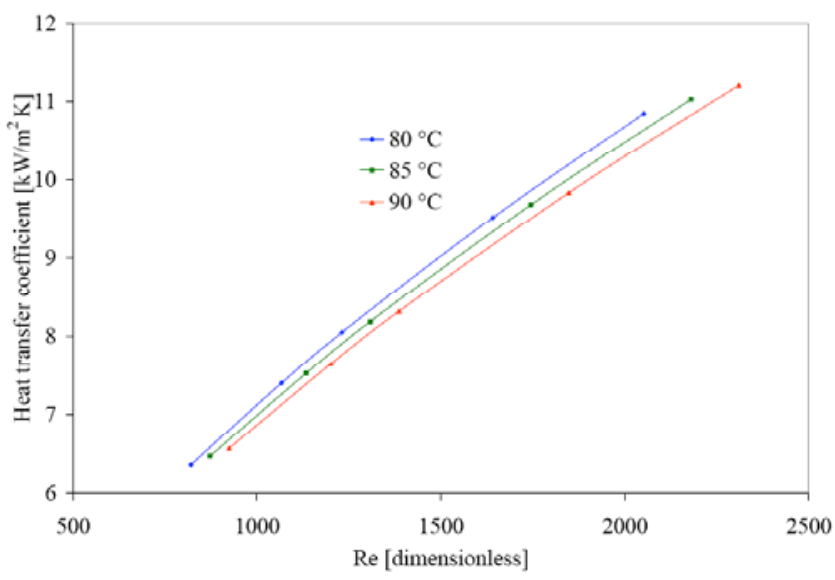

Fig. (9). Heat transfer coefficient against Reynolds number for different temperatures.

Fig. (10) shows the heat transfer coefficient for different heat load and different mass flows of the alternative energy. The highest heat transfer coefficients are obtained for 4 $\mathrm{L} / \mathrm{min}$ and temperature of $90{ }^{\circ} \mathrm{C}$. These values correspond to the highest Reynolds number of 2310. These conditions promote heat transfer.

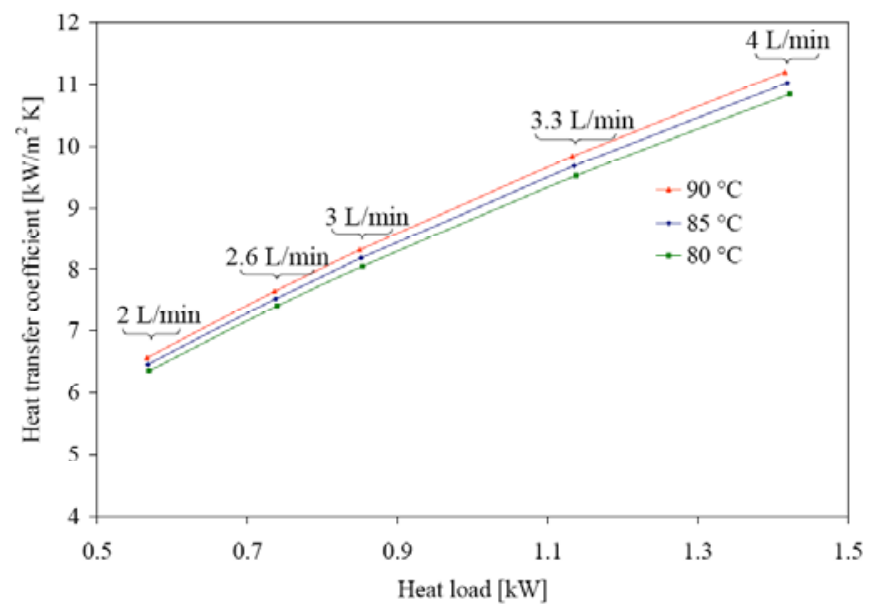

Fig. (10). Heat transfer coefficient against heat load for different temperatures.
For the mathematical model it is considered that the steam generation begins once the working solution reaches the highest temperature, this is about $0.27 \mathrm{~m}$ of the plate (Fig. 11). The steam generation is reached almost at the end of the plate. The concentration of the solution increases when the steam generation begins as it is shown in Fig. (11).

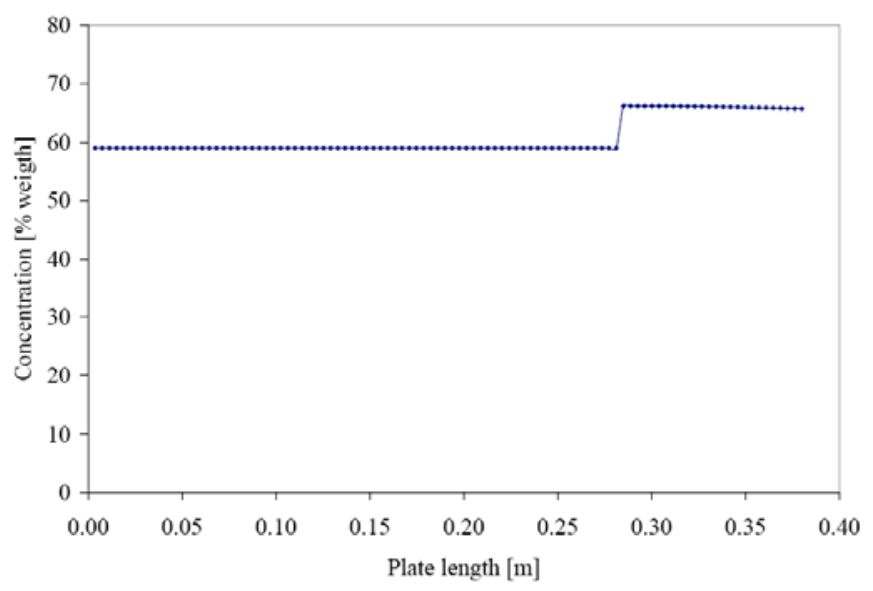

Fig. (11). Concentration profile along the plate.

According to this concentration profile, the properties for the working solution are calculated as a function of the temperature and the concentration. In Fig. (12) the profiles for density and viscosity are shown. The density remains almost constant during the heating of the solution; when the steam generation begins, the values of the density are increased due to the increase in the concentration of the working solution. The viscosity shows a light decrease while the solution is being heated.

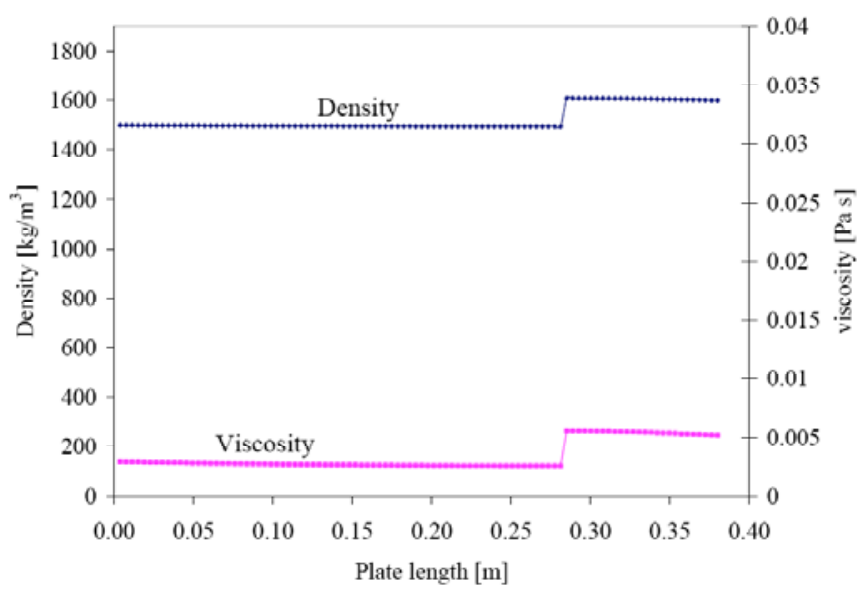

Fig. (12). Profiles of density and viscosity of the working solution.

Fig. (13) shows the profiles of the specific heat and enthalpy. The enthalpy shows a higher influence of the temperature in comparison to other properties. Its values are increased while the solution is being heated. The specific heat shows a decrease when the steam generation begins and the concentration is increased. 


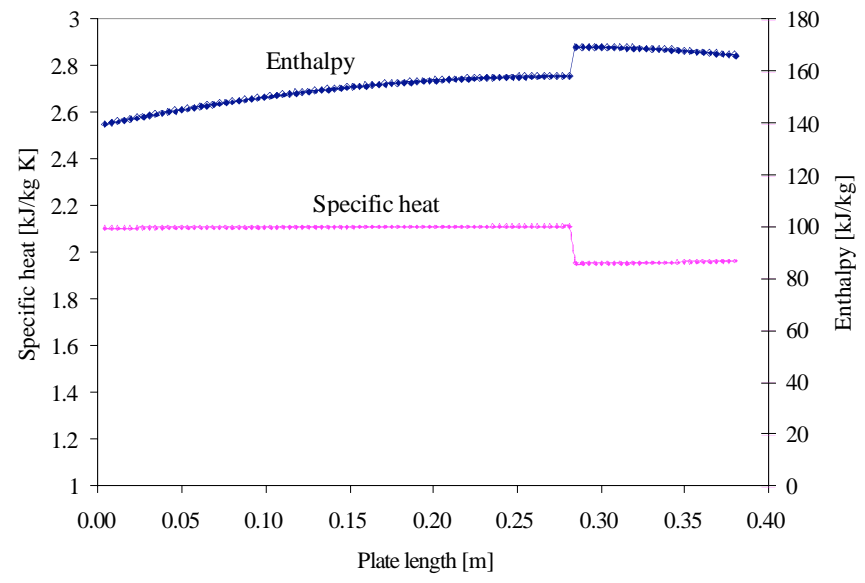

Fig. (13). Profiles for the specific heat and enthalpy for the working solution.

This is the first work where the heat transfer coefficients are instantly calculated for the solution water - Carrol ${ }^{\mathrm{TM}}$, therefore, it is not possible to compare these results with previously reported data or with another correlation. However, M. de Vega [32] used the equation 7 reported by Hsieh and Lin [31] for the solution water - lithium bromide.

$$
h_{l i q}=0.2\left(\frac{k_{l i q}}{D_{h}}\right) \operatorname{Re}^{0.7} \operatorname{Pr}^{1 / 3}\left(88 B o^{0.5}\right)
$$

For the similarity of the solution water - Carrol ${ }^{\mathrm{TM}}$ with the solution water - lithium bromide, it was decided to compare the coefficient of heat transfer obtained with the equation 6 versus those calculated with this correlation. The results obtained with equation 6 were also compared with the correlation of Han et al., [33] for two-phase flow:

$$
h_{l i q}=G e_{1}\left(\frac{k_{l i q}}{D_{h}}\right) \operatorname{Re}^{G e_{2}} B o^{0.3} \operatorname{Pr}^{0.4}
$$

Where $\mathrm{Ge}_{1}$ y $\mathrm{Ge}_{2}$ depends of the plate geometry:

$$
\begin{gathered}
G e_{1}=2.81\left(\frac{\Lambda}{D_{h}}\right)^{-0.041}\left(\frac{\pi}{2}-\beta\right) \\
G e_{2}=0.746\left(\frac{\Lambda}{D_{h}}\right)^{-0.082}\left(\frac{\pi}{2}-\beta\right)
\end{gathered}
$$

$\Lambda$ is the heat exchanger pitch.

Fig. (14) shows the heat transfer coefficients for the working solution, before the steam generation begins. The solution has a concentration of $58 \%$.

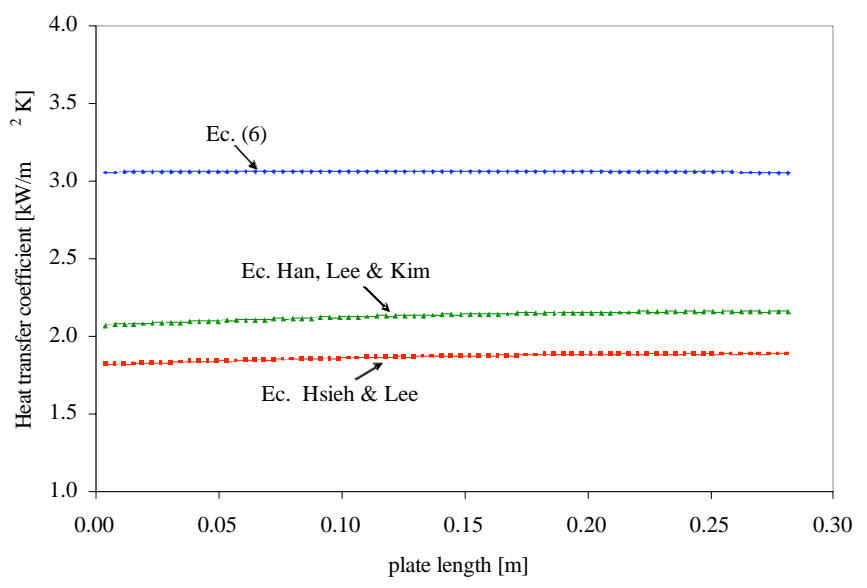

Fig. (14). Heat transfer coefficients for the working solution.

It is possible to observe that the difference of the values between the correlations is of $14 \%$. The difference of these correlations compared to the coefficient calculated with equation 6 is of $68 \%$ with the equation of Hsieh and Lee, and $47 \%$ with the equation of Lee and Kim. This difference could be explained because the coefficient calculated with equation 6 is in function of the global heat transfer coefficient and the heat transfer coefficients of the heater system; while the correlations are in function of the dimensionless parameters such as Pr, Re, and Bo number. Those parameters take into consideration the concentration and the physical properties of the solution water - Carrol ${ }^{\mathrm{TM}}$. The heat transfer coefficients for the working solution are smaller than the heater system. It will be important to obtain the highest coefficients for the alternative energy source and for the working solution, that way the steam generation will be improved and, therefore a higher level of upgrade energy will be achieved.

\section{CONCLUSIONS}

A thermal analysis for a steam generator in an energy upgrade system has been shown. The steam generator is the starter component of this system that use alternative energy. Heat transfer coefficients for the alternative energy source and for the working solution water-Carrol ${ }^{\mathrm{TM}}$ were obtained. The heat transfer coefficients for the alternative energy source were obtained with two different correlations with very close results. The heat transfer coefficients increases with the heat load. The highest heat transfer coefficients are obtained for a Reynolds number of 2300 , temperature of the alternative energy source of $90{ }^{\circ} \mathrm{C}$ and mass flows of 4 $\mathrm{L} / \mathrm{min}$. The heat transfer coefficients for the working solution were calculated with two different correlations with differences close to $14 \%$, obtaining values between 1.8 and 2.1 $\mathrm{kW} / \mathrm{m}^{2} \mathrm{~K}$. The heat transfer coefficients for the working solution are smaller than the obtained for the alternative energy source.

\section{ACKNOWLEDGEMENT}

The authors wish to thank the project "Development and application of a self-sufficient and sustainable solar-thermal refrigeration system for conservation of perishable products in communities far from the electrical grid" for its partial support for this work. 


\section{NOMENCLATURE}

$\begin{array}{lll}\mathrm{A} & = & \text { area }\left[\mathrm{m}^{2}\right] \\ \mathrm{Bo} & = & \text { boiling number } \\ \mathrm{D}_{\mathrm{h}} & = & \text { hydraulic diameter }[\mathrm{m}] \\ \mathrm{H} & = & \text { enthalpy }[\mathrm{kJ} / \mathrm{kg}] \\ \mathrm{h} & = & \text { heat transfer coefficient }\left[\mathrm{kW} / \mathrm{m}^{2} \mathrm{~K}\right] \\ \mathrm{k} & = & \text { thermal conductivity }[\mathrm{kW} / \mathrm{m} \mathrm{K}] \\ \mathrm{m} & = & \text { mass flow }[\mathrm{L} / \mathrm{min}] \\ \mathrm{Pr} & = & \text { Prandtl number } \\ \mathrm{Q} & = & \text { heat load }[\mathrm{kW}] \\ \mathrm{q} & = & \text { heat rate }\left[\mathrm{kW} / \mathrm{m}^{2}\right] \\ \mathrm{Re} & = & \text { Reynolds number } \\ \mathrm{T} & = & \text { temperature }\left[{ }^{\circ} \mathrm{C}, \mathrm{K}\right] \\ \mathrm{U} & = & \text { global heat transfer coefficient }\left[\mathrm{kW} / \mathrm{m}^{2}\right. \\ \mathrm{X} & = & \text { K }] \\ \beta & = & \text { concentration }[\% \text { weight }] \\ \Delta \mathrm{T}_{\mathrm{lm}} & = & \text { log mean difference of temperatures } \\ \Delta \mathrm{z} & = & \text { wall thickness }[\mathrm{m}] \\ \mathrm{Su} & & \end{array}$

Subscript

$\begin{array}{lll}\mathrm{AB} & = & \text { absorber } \\ \mathrm{EV} & = & \text { evaporator } \\ \mathrm{CO} & = & \text { condenser } \\ \mathrm{GE} & = & \text { generator } \\ \text { vap } & = & \text { vapor } \\ \text { liq } & = & \text { liquid working solution } \\ \text { heat } & = & \text { heater system } \\ \text { in } & = & \text { inlet condition } \\ \text { out } & = & \text { outlet condition } \\ \text { wall } & = & \text { wall of the plate }\end{array}$

\section{REFERENCES}

[1] World Energy Outlook, 2007. World energy outlook: China and India Insights, International Energy Agency. Part A, chapter 2, 119 - 120. http://www.iea.org/textbase/nppdf/free/2007/weo_2007.pdf

[2] Zogg, R. A.; Feng, M. Y.; Westphalen, D. Guide to Developing Air-Coled LiBr Absorption for Combined Heat and Power Applications U.S Department of Energy, 2005.

[3] Romero, R. J. Thesis, Universidad Nacional Autónoma de México, 2001.

[4] Eisa, M. A. R. Applications of heat pumps in chemical processing. Energy Convers. Manage., 1996, 37 (3), 369-377.

[5] Smolena, S.; Budnik-Rodzb, M. Low rate energy use for heating and in industrial energy supply systems-some technical and economical aspects. Energy, 2006, 31, 2588-2603.

[6] Wang, X.; Shi, L.; Yin, J.; Zhu, M. S. A two-stage heat transformer with $\mathrm{H}_{2} \mathrm{O} / \mathrm{LiBr}$ for the first stage and 2,2,2-trifluoroethanol (TFE)/N-methy1-2-pyrrolidone (NMP)for the second stage. Appl. Energy, 2002, 71, 235-249.

[7] Mostofizadeh, C.; Kulick, C. Use of a new type of heat transformer in process industry. Appl. Therm. Eng., 1998, 18, 857-874.
[8] Göktun, S.; Er, I. D. Performance analysis of an irreversible cascaded heat transformer. Appl. Energy, 2002, 72, 529-539.

[9] Ziegler, F. Recent developments and future prospects of sorption heat pumps systems. Int. J. Therm. Sci., 1999, 38, 191-208.

[10] Ma, X.; Chen, J.; Li, S.; Sha, Q.; Liang, A.; Li, W.; Zhang, J.; Zheng, G.; Feng, Z. Application of absorption heat transformer to recover waste heat from a synthetic rubber plant. Appl. Therm. Eng., 2003, 23, 797-806.

[11] Costa, A.; Bakhtiari, B.; Schuster, S.; Paris, J. Integration of absorption heat pumps in a Kraft pulp process for enhanced energy efficiency. Energy, 2009, 34 (3), 254-260.

[12] Huicochea, A.; Sequeiros, J.; Romero, R.J. Portable water purification system integrated to a heat transformer. Desalination, 2004, 165, 385-391.

[13] Seseña, M.; Silva, S.; Kumar, Y.; Sequeiros, J. Propuesta de adaptación de colectores solares como fuente de energía para un equipo portátil de purificación de agua integrado a un transformador térmico: Proceedings of XXVI Mexican Academy of research and teaching in chemical engineering Meeting. Guerrero, México, may 3-6 2005. Mexican Academy of research and teaching in chemical engineering, México, 2005, pp. 45-50.

[14] Slesarenko, V.V. Heat pumps as a source of heat energy for desalination of seawater. Desalination, 2001, 139, 405-410.

[15] Sözen, A.; Yücesu, H.S. Performance improvement of absorption heat transformer. Renewable Energy, 2007, 32 (2), 267-284.

[16] Shitara, A.; Nishiyama, N. Study on heat transfer of plate-fin type generator for absorption machine, Proceedings of 19th International congress of refrigeration. Netherlands, 1995; pp. 72-79.

[17] Roriz, L.; M. A. y Mendes, L. F. Study of a plate heat exchanger desorber with a spray column for a small solar powered absorption machine. 3rd International conference on heat powered cycles, Larnaca, Cyprus. 10th - 13th October 2004.

[18] Táboas, F.; Vallés, M.; Bourouis, M.; Coronas, A. Pool boiling of ammonia/water and its pure components: comparison of experimental data in the literature with the predictions of standard correlations. Int. J. Refrigerat., 2007, 30 (5), 778-788.

[19] Rivera, W.; Vélez, V.; Xicale, A. Heat transfer coefficients in two phase flow for mixtures used in solar absorption refrigeration systems. Solar Energy Mater. Solar Cells, 2000, 63, 401-411.

[20] Rivera, W.; Xicale, A. Heat transfer coefficients in two phase flow the water / lithium bromide mixture used in solar absorption refrigeration systems. Solar Energy Mater. Solar Cells, 2001, 70, 309320.

[21] Yan, Y.Y.; Lin, T.F. Evaporation heat transfer and pressure drop of refrigerant, R134a in a small pipe. Int. J. Heat Mass Transf., 1998, 41, 4183-4194.

[22] Sripattrapan, W.; Wongwises, S. Two-phase flow of refrigerants during evaporation under constant heat flux in a horizontal tube. Int. Commun. Heat Mass Transf., 2005, 32, 386-402.

[23] Lee, H. J.; Lee, S. Y. Heat transfer correlations for boiling flows in small rectangular horizontal channels with low aspect ratios. Int. J. Multiphase Flow, 2001, 27, 2043-2062.

[24] García-Cascales, J.R.; Vera-García, F.; Corberán-Salvador, J.M.; Gonzálvez-Maciá, J. Assessment of boiling and condensation heat transfer correlations in the modelling of plate heat exchangers. Int. J. Refrigerat., 2007, 30, 1029-1041.

[25] Herold, K. E.; Radermacher, R.; Klein, S. A. Absorption chillers and Heat pumps. CRC press: Boca Raton, Fl: USA, 1996.

[26] Sözen A. Effect of irreversibilities on performance of an absorption heat transformer used to increase solar pond's temperature. Renewable Energy, 2003, 29, 501-515.

[27] Rivera, W.; Romero, R.J. Evaluation of a heat transformer powered by a solar pond. Solar Energy Mater. Solar Cells, 2000, 63, 413422.

[28] Bogaert, R.; Bölcs, A. Global performance of a prototype brazed plate heat exchanger in a large Reynolds number range. Exp. Heat Transf., 1995, 8, 293-311.

[29] Chisholm, D.; Wanniarachchi A.S. Layout of plate heat exchangers. ASME/JSME Therm Eng. Proc., 1991, 4, 433-438.

[30] Reimann, R.; Biermann, W.J. Development of a single family absorption chiller for use in solar heating and cooling system. Phase III Final Report, Prepared for the U. S. Department of Energy under contract EG-77-C-03-1587, Carrier Corporation 1984. 
[31] Hsieh, Y. Y.; Lin, T. F. Saturated flow boiling heat transfer and pressure drop of refrigerant R-410A in a vertical plate heat exchanger. Int. J. Heat Mass Transf., 2002, 45, 1033-1044.

[32] De Vega, M.; Almendros-Ibañez, J.A.; Ruiz, G. Performance of a $\mathrm{LiBr}-$ water absorption chiller operating with plate heat exchangers. Energy Convers. Manage., 2006, 47, 3393-3407.
[33] Han, D.H.; Lee, K.J.; Kim, Y.H. Experiments on characteristics of evaporation of R410a in brazed plate heat exchangers with different geometric configurations. Appl. Therm. Eng., 2003, 23, 12091225 .

(C) Sliva et al.; Licensee Bentham Open.

This is an open access article licensed under the terms of the Creative Commons Attribution Non-Commercial License (http://creativecommons.org/licenses/by-nc/3.0/) which permits unrestricted, non-commercial use, distribution and reproduction in any medium, provided the work is properly cited. 